\title{
Utilising Caging Techniques to Investigate Metal Assimilation in Nucella lapillus, Mytilus edulis and Crassostrea gigas at Three Irish Coastal Locations
}

\author{
Michelle Giltrap \\ Techological University Dublin, michelle.giltrap@tudublin.ie \\ Ailbhe Macken \\ Technological University Dublin, ailbhe.macken@tudublin.ie \\ Maria Davoren \\ Technological University Dublin, Maria.davoren@tudublin.ie

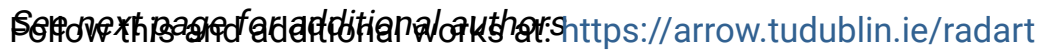 \\ Part of the Environmental Chemistry Commons
}

\section{Recommended Citation \\ Giltrap, M., Macken, A., Davoren, M., McGovern, E., Foley, B., Larsen, M., White, J., McHugh, B.: Utilising caging techniques to investigate metal assimilation in Nucella lapillus, Mytilus edulis and Crassostrea gigas at three Irish coastal locations. Estuarine, Coastal and Shelf Science, vol. 132, 1 November 2013, p. 77-86. doi:10.1016/j.ecss.2011.11.040}

This Article is brought to you for free and open access by the Radiation and Environmental Science Centre at ARROW@TU Dublin. It has been accepted for inclusion in Articles by an authorized administrator of ARROW@TU Dublin. For more information, please contact arrow.admin@tudublin.ie, aisling.coyne@tudublin.ie, gerard.connolly@tudublin.ie.

Funder: Technology Sector Research: Strand III: Core Research Strengths and from Technological University Dublin's Capacity Building Scheme (CaBS) for Strategic Research.

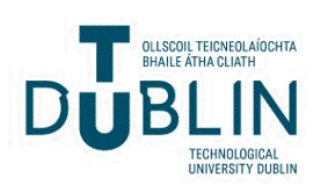




\section{Authors}

Michelle Giltrap, Ailbhe Macken, Maria Davoren, Evin McGovern, Barry Foley, Martin Larsen, Jonathan White, and Brendan McHugh

This article is available at ARROW@TU Dublin: https://arrow.tudublin.ie/radart/40 


\title{
Utilising caging techniques to investigate metal assimilation in Nucella lapillus, Mytilus edulis and Crassostrea gigas at three Irish coastal locations
}

\author{
Michelle Giltrap ${ }^{\mathrm{a}, \mathrm{c}, *}$, Ailbhe Macken ${ }^{\mathrm{b}}$, Maria Davoren ${ }^{\mathrm{b}}$, Evin McGovern ${ }^{\mathrm{a}}$, \\ Barry Foley ${ }^{\mathrm{c}}$, Martin Larsen ${ }^{\mathrm{d}}$, Jonathan White ${ }^{\mathrm{a}}$, Brendan McHugh ${ }^{\mathrm{a}}$ \\ a Marine Institute, Rinville, Oranmore, County Galway, Ireland \\ ${ }^{\mathrm{b}}$ Radiation and Environmental Science Centre, FOCAS Institute, Dublin Institute of Technology, Kevin Street, Dublin 2, Ireland \\ 'School of Chemical and Pharmaceutical Sciences, Dublin Institute of Technology, Kevin Street, Dublin 2, Ireland \\ ${ }^{\mathrm{d}}$ National Environmental Research Institute, Department of Marine Ecology, University of Aarhus, 4000 Roskilde, Denmark
}

\section{A R T I C L E I N F O}

\section{Article history:}

Available online 19 December 2011

\section{Keywords:}

metal uptake

caging study

Nucella lapillus

Crassostrea gigas

Mytilus edulis

stable isotopes

\begin{abstract}
A B S T R A C T
Pollution by metals has been of increasing concern for a number of decades but at present, the mechanism of metal accumulation in sentinel species is not fully understood and further studies are required for environmental risk assessment of metals in aquatic environments. The use of caging techniques has proven to be useful for assessment of water quality in coastal and estuarine environments. This study investigates the application of caging techniques for monitoring uptake of 20 elements [ $\mathrm{Li}, \mathrm{Na}, \mathrm{Mg}, \mathrm{Al}, \mathrm{P}$, $\mathrm{K}, \mathrm{Ca}, \mathrm{V}, \mathrm{Cr}, \mathrm{Mn}, \mathrm{Fe}, \mathrm{Ni}, \mathrm{Co}, \mathrm{Cu}, \mathrm{As}, \mathrm{Sb}, \mathrm{Pb}, \mathrm{Hg}, \mathrm{Cd}$ and $\mathrm{Zn}]$ in three marine species namely Nucella lapillus, Mytilus edulis and Crassostrea gigas. Stable isotopes were used to determine predatory effects and also used for modelling metal uptake in test species and to track nutrient assimilation. Metal levels were monitored at three different coastal locations, namely Dublin Bay, Dunmore East and Omey Island over 18 weeks. Significant differences in concentrations of $\mathrm{Mn}, \mathrm{Co}$ and $\mathrm{Zn}$ between mussels and oysters were found. Correlations between cadmium levels in N. lapillus and $\delta^{13} \mathrm{C}$ and $\delta^{15} \mathrm{~N}$ suggest dietary influences in $\mathrm{Cd}$ uptake. Levels of $\mathrm{Zn}$ were highest in C. gigas compared to the other two species and levels of $\mathrm{Zn}$ were most elevated at the Dunmore East site. Copper levels were more elevated in all test species at both Dublin Bay and Dunmore East. Mercury was raised in all species at Dunmore East compared to the other two sites. Biotic accumulation of metals in the test species demonstrates that caging techniques can provide a valid tool for biomonitoring in metal impacted areas.
\end{abstract}

(c) 2011 Elsevier Ltd. All rights reserved.

\section{Introduction}

Goldberg (1975) first proposed the mussel-watch concept, this having since being adopted by a number of International monitoring programmes including the Irish monitoring programme under the direction of OSPAR (OSPAR, 2005). These programmes are primarily based on a quantitative bio-indicator concept, using the ability of marine bivalves (usually mussels/oysters) to concentrate and accumulate contaminants in their tissues. Utilisation of such sentinel species offers a time-integrated response to contaminant levels in the relevant environmental compartment and is considered much more efficient than direct/spot measurements in the water (Goldberg, 1975).

\footnotetext{
* Corresponding author. Zoology Department, Trinity College Dublin, Dublin 2 Ireland.

E-mail address: giltrapm@tcd.ie (M. Giltrap).
}

Interpretation difficulties can result as a consequence of contaminant dynamics, environmental factors (e.g. temperature, trophic conditions, contamination level, salinity, $\mathrm{pH}$, redox potential, dissolved organic carbon, temperature, and food availability) (Bjerregaard and Depledge, 1994; Sunda and Huntsman, 1998). Also difficulties in understanding arise from associated interactions with the physiology (size, sex, sexual maturity, reproduction stages, and seasonal growth cycles) of the test species (Cossa, 1989; Rainbow et al., 1990; Bjerregaard and Depledge, 1994; Wang and Eckmann, 1994; Wright, 1995; Lee and Luoma, 1998; Lee et al., 1998). A better understanding of the mechanism of metals accumulation/ elimination is fundamental to ensuring that test species are appropriately selected in order to deliver experimental, environmental and or food safety related goals.

Blackmore and Wang (2003a) have reviewed whether differences in the measured concentrations in biomonitors reflect local bioavailabilities or reflect inter-site differences in the organism's 
physiology and biochemistry, suggesting that biomonitoring data from different areas and even utilising different mussel species may be directly comparable thus supporting the concept of biomonitoring/“Mussel-Watch" programs. Such conclusions confirm that with appropriately selected test species and methodologies (e.g. caging techniques in areas where species may be absent) that caging of sentinel species can provide valuable information on (metal) pollutant levels in the marine environment.

\subsection{Accumulation/elimination and toxicity of metals in marine organisms}

Significant differences can exist in the abilities of marine species to accumulate metals. Silver, cadmium, zinc, copper, and mercury are generally accumulated to much higher concentrations in oysters as compared to mussels. Oysters are known to accumulate high concentrations of zinc in the form of detoxified granules while mussels excrete a portion of accumulated zinc in granules from the kidney. Thus oysters are strong accumulators of zinc whereas mussels are weak net accumulators or partial regulators of zinc (Rainbow, 1992). Mussels have been reported to accumulate relatively low cadmium and zinc concentrations while oysters have been shown to contain relatively high cadmium and zinc concentrations compared to other marine species. Such information is fundamental when implementing monitoring programs where zinc levels are to be determined. It has additionally been reported that even in unpolluted waters, neogastropods such as Nucella lapillus, Murex brandaris and Buccinum undatum can accumulate cadmium at high concentrations (Bouquegneau and Martoja, 1982).

Toxicity of metals to marine organisms does not solely depend on total accumulated tissue concentrations but is related to a threshold concentration of internal metabolically available metal (Rainbow, 2007). Toxicity is induced when the rate of metal uptake from all sources exceeds the combined rates of detoxification and excretion (if present) of the metal concerned. When metals first enter the body of crustaceans (after uptake from solution through permeable ectodermal surfaces or across the endoderm of the gut) they will initially be metabolically available, i.e. will have the potential to bind to molecules in the receiving cell or elsewhere in the body after internal transport via the haemolymph (Rainbow, 2007). Essential metals (e.g. zinc, copper) are then available to bind to sites where they can play an essential role in metabolic processes, or, if present in excess may cause toxic effects. Excesses of essential metal (and all non-essential metals) must be detoxified, e.g. bound in a storage organ within the body of the animal. Such bound forms in a "detoxified store" may be temporary in which they may be excreted (Rainbow, 1998, 2002). Detoxification can also occur in the soluble phase. Certain trace metals e.g. zinc, copper, cadmium, silver and mercury, are associated with, and induce, metallothioneins, low molecular weight cytosolic proteins involved in the cellular regulation and detoxification of these metals (Roesijadi, 1993; Amiard et al., 2006). The presence of sulphur in cysteine residues in these proteins provides the high metal affinity of the molecule, sequestering metals in the cytoplasm and reducing their metabolic availability. Once the uptake rate of a trace metal is lower than the combined rates of detoxification and excretion, then the metal will not accumulate in the metabolically available component and toxicity will not ensue (Rainbow, 2002; Marsden and Rainbow, 2004). Conversely if the uptake rate exceeds that of excretion/detoxification then the level of metabolically available metal will exceed a threshold and toxic metal can then bind to sites where they can interfere with normal metabolic functioning, inducing a potential toxic effect.

Differences in tissue metal concentrations can therefore be described as a function of the interaction of the physicochemical characteristics of the contaminant, environmental factors, physiology of the test species, and inter-specific differences in the biokinetics of uptake and elimination. Summary factors influencing metal accumulation in a number of marine species relevant to this work are further discussed below.

\subsection{Factors influencing metals uptake}

\subsubsection{Physiological factors influencing metals uptake}

It is not the purpose of this paper to review factors influencing metals assimilation and toxicity, however assimilation efficiencies (AE) (Wang and Rainbow, 2006), species specific differences in the uptake rate constants of dissolved metals, and differences in metal efflux rates are important in determining inter-specific differences in accumulated metal concentrations in bivalves.

Biokinetic parameters (e.g., dietary assimilation, dissolved uptake and efflux rates) are therefore important in determining interspecies differences, while other parameters (such as feeding rate, growth rate) can be of less importance in metal accumulation. Since many species living in the same geochemical environment display contrasting metal concentrations, geochemical parameters (metal concentrations in water and food) may be less important in explaining the interspecies difference in metal body concentrations (Wang and Rainbow, 2005).

\subsubsection{Sub-cellular fractionation of metals}

It is now established that aquatic invertebrates possess diverse strategies in the handling and storage of accumulated metals; thus great differences in tissue metal concentrations across different phyla can exist (Rainbow, 1998, 2002; Wang and Rainbow, 2005). Wang and Rainbow (2005) discuss the importance of the subcellular distribution of metals in bivalves and suggest that metals are generally fractionated into five operationally defined subcellular pools, with different metals having contrasting associations with different sub-cellular pools, depending on species, exposure history, and other conditions. This is important to remember when utilising a range of species as bioindicators of metal exposure.

\subsubsection{Environmental factors influencing metal uptake}

Salinity conditions can be critical in influencing metal accumulation in organisms living in different environments as variations can directly affect the speciation potential of metals in the water column and thus both the metal uptake rate from solution and potentially the physiology of organisms. Factors leading to an increase in the local proportion of free ion concentration may increase metal bioavailability and thus increase uptake and toxicity, although such relationships especially in field situations can be complex (Pan and Wang, 2004; Chuang and Wang, 2006). Blackmore and Wang (2003b) have demonstrated that changes in salinity can cause eco-physiological changes in particular organisms and subsequently cause an inter-populational difference in dissolved metal uptake rates.

\subsection{Use of caging studies}

The translocation of sentinel species from a reference site to the study areas has been demonstrated as a useful strategy for the assessment of water quality in coastal and estuarine environments, either through bioaccumulation and/or biomarker response (Regoli and Orlando, 1994; Riveros et al., 2003; Romeo et al., 2003). The use of cages to transplant gastropods for tributyltin induced biological effect studies has also been previously reported (Quintela et al., 2000; Smith et al., 2006). Caging of marine species facilitates the investigation in areas where native organisms are absent and 
reduces the influence of genetic/population differences, of seasonal variability or adaptive phenomena. The use of caged organisms provides a time-integrated assessment of environmental quality over a translocation period, and reveals the early biological effects induced by accumulated pollutants. This present study formed part of an additional study whereby caging of Nucella lapillus and Crassostrea gigas species demonstrated a high level of imposex (3.25 VDSI and 2.375 RPSI) and a high degree of shell thickening (shell index: 9.20) after only an 18 week period in a TBT contaminated site (Giltrap et al., 2009). The same animals were analysed for both studies using the caging study to generate a multitude of data.

\subsection{Stable isotopes in describing nutrient assimilation and metal uptake}

It is becoming increasingly appreciated that uptake of trace metals from the diet may be the major source of metals for many aquatic invertebrates. The measurement of stable isotopes (SI) of nitrogen and carbon in marine species has previously been employed to provide a quantitative, continuous variable for studying relative trophic status, dietary preferences and the biomagnification of contaminants within complex food webs (DeNiro and Epstein, 1978; Minagawa and Wada, 1984; Rounick and Winterbourn, 1986; Peterson and Fry, 1987). The utilisation of $\delta^{15} \mathrm{~N}$ to assess trophic position of organisms has been demonstrated by Post (2002) who indicated an approximate change in one part per thousand is indicative of a higher/lower trophic status. The potential for the application of SI techniques to caging studies for metals uptake is evaluated in this paper.

The aims of this study are to investigate: (1) the potential application of caging techniques for the monitoring of metals uptake in three marine species (Mytilus edulis, Crassostrea gigas and Nucella lapillus), (2) levels of metals in filter-feeding mussels and oysters and in the predatory gastropod (at $t=0$ and $t=18$ weeks) transplanted to three Irish coastal locations, (3) similarities/differences in the metals accumulation pattern in the filter-feeding organisms and in the gastropods, (4) the potential application of stable isotope methodologies to track nutrient assimilation in these species, (5) a potential role for stable isotopes in modelling metal uptake in test species, and finally (6) the potential for application of caging studies to support biomarker/ecotoxicological studies.

\section{Materials and methods}

\subsection{Selection of sites and caging study methodology}

Two test locations were selected for this study, namely Dublin Bay $\left[53^{\circ} 21^{\prime} 0^{\prime \prime} \mathrm{N}, 6^{\circ} 10^{\prime} 12^{\prime \prime} \mathrm{W}\right]$, Dunmore East Harbour $\left[52^{\circ} 8^{\prime} 51^{\prime \prime} \mathrm{N}\right.$, $\left.6^{\circ} 59^{\prime} 31^{\prime \prime} \mathrm{W}\right]$ and one control site, Omey Island $\left[53^{\circ} 31^{\prime} 48^{\prime \prime} \mathrm{N}\right.$, $\left.10^{\circ} 10^{\prime} 11.9994^{\prime \prime} \mathrm{W}\right]$. Mussels and oysters were obtained from another control site in Galway bay $53^{\circ} 09^{\prime} .2728^{\prime \prime} \mathrm{N}, 9^{\circ} 04^{\prime} 0384^{\prime \prime} \mathrm{W}$ while gastropods were obtained from Omey Island. Dublin is the main shipping port on the east coast of Ireland. The chosen experimental site is tidal and is associated with a fixed navigation mark at the entrance to the estuary sheltered by two breakwaters (the North and South Bull Wall) extending into Dublin Bay. Dunmore East is a fishing port with boat-lifting facilities on the south coast of Ireland with a history of elevated levels of metals in the sediment (Enterprise Ireland, unpublished data). The cage at this location was fixed to a supporting boulder below the harbour. Omey Island off County Galway in the West of Ireland has no industrialisation and very few urban surroundings. This area was selected as a control location for transplantation. Oysters and mussels were sourced from a control location in County Clare and gastropods were sourced from Omey Island off County Galway.
The caging study methodology including collection of test species (oysters, mussels and gastropods) at $t=0$ and $t=18$ weeks and measurements of biological effects was performed as described in Giltrap et al. (2009). Briefly, eight gastropods and approximately $1 \mathrm{~kg}$ of blue mussels acting as a primary food source were placed together in rigid plastic Northwest Trays ${ }^{\circledR}(51 \mathrm{~cm}$ by $51 \mathrm{~cm}$ and $53 \mathrm{~mm}$ deep with a bar mesh of $5 \mathrm{~mm}$ ). At each site, 10-12 stacked trays containing both gastropods and mussels (mixed for predation) and one tray containing only Crassostrea gigas (separate), were securely fixed at each test site. For metal analysis, 50 mussels, 50 oysters and 100 gastropods were sampled from the cages. The experimental period lasted from April to August 2007 ( $t=18$ weeks) based on previous studies demonstrating the acclimatization period required for development of biological effects (Quintela et al., 2000; Smith et al., 2006). Trays were permanently submerged at Omey Island and Dublin Bay, while at Dunmore East the tray stack was exposed at low tide. Whole tissues remaining after biological effects measurements were completed were pooled on a species basis and analysed for a variety of elements as described below.

\subsection{Biota metal analysis}

A total of 20 elements were analysed in freeze-dried tissues from each of the test species. The methodology for elemental analysis is briefly described. Concentrations were quantified using a 7500 cs Inductively Coupled Plasma-Mass Spectrometer (ICP-MS) (Agilent, Santa Claire, United States) with a Babington nebulizer connected to a cooled spray chamber $\left(5^{\circ} \mathrm{C}\right)$, introducing the mist into an argon (Ar) plasma operating at $1500 \mathrm{~W}$ with $15 \mathrm{~L} \mathrm{Ar} \mathrm{min}^{-1}$. Standard mass-overlap correction from United States Environmental Protection Agency method 6020 was used to correct the signal before the calibration was calculated, and drift was corrected by using rhodium, iridium and indium as internal standards. Zinc was determined using acetylene-air flame atomic absorption on a Perkin Elmer 5100 PC (Perkin Elmer Corporation, Massachusetts, United States); cadmium was determined by graphite furnace of the same instrument, using palladium-magnesium as modifier in a platform furnace and finally mercury was determined using cold vapour atomic absorption spectrometry on a Perkin Elmer flow injection mercury system (FIMS) 400 (Strand et al., 2005). All methods were based on external standard curves.

\subsection{Stable isotope analysis}

The methodology used for stable isotopes analysis in tissues is described in Giltrap et al. (2009). Briefly, lipid free tissues were freeze-dried and approximately $1 \mathrm{mg}$ of sample was combusted in the presence of $\mathrm{O}_{2}$ and $\mathrm{Cr}_{2} \mathrm{O}_{3}$ at $1700{ }^{\circ} \mathrm{C}$ in a NCS 2500 element analyser. Reduction of $\mathrm{NO}_{\mathrm{x}}$ to $\mathrm{N}_{2}$ was then performed in a $\mathrm{Cu}$ oven at $650{ }^{\circ} \mathrm{C}$. Water was removed in a $\mathrm{KMnO}_{4}$ chemical trap before separation of $\mathrm{N}_{2}$ and $\mathrm{CO}_{2}$ on a $3 \mathrm{~m}$ Poraplot quadrupole gas chromatograph column prior to on-line detection of $\delta^{15} \mathrm{~N}$ and $\delta^{13} \mathrm{C}$ using a Micromass Optima Isotope Ratio Mass Spectrometer Differences in stable isotope abundances are expressed by $(\delta)$ notation as the deviation from standards in parts per thousand by, $\delta \mathrm{X}=\left[\left(\mathrm{R}_{\text {sample }} /\right.\right.$ $\left.\left.R_{\text {standard }}\right)-1\right] \times 1000$ where $X$ relates to ${ }^{13} \mathrm{C}$ or ${ }^{15} \mathrm{~N}$ and $\mathrm{R}$ is the corresponding ratio ${ }^{13} \mathrm{C} /{ }^{12} \mathrm{C}$ or ${ }^{15} \mathrm{~N} /{ }^{14} \mathrm{~N}$. R standard for ${ }^{13} \mathrm{C}$ and ${ }^{15} \mathrm{~N}$ relate to Pee Dee Belemnite standard and atmospheric $\mathrm{N}_{2}$, values respectively.

\subsection{Quality control of data}

A full quality control programme was completed for stable isotope analysis was completed as described in Giltrap et al. (2009). Quality assurance for trace elements was validated by the use of certified reference material (CRM) NIST 2976. All trace elements were within 
$30 \%$ of the target value for the metals, aluminium, potassium, iron, nickel, cobalt, copper and lead fell within 15\% (on ICP-MS, RSD of 3-12\% for 5 NIST digestions) zinc (Flame Atomic Absorption), cadmium (Graphite Furnace Atomic Absorption) and mercury (Cold Vapour) where all within $15 \%$ (RSD $<5 \%$ ). The RSD on replicate digestions was typically $2-5 \%$ for AAS and 3-12\% for ICP-MS.

\subsection{Graphical data for metals results in biota}

For analysis purposes, graphs detailing increases/decreases in element concentrations in each of the three test species relative to their appropriate $t=0$ reference sample were completed. Subtracting the $\log (x+1)$ metal concentration in the $t=18$ week samples from that of the $t=0$ week reference sample has the effect of "normalizing" datasets to allow for visualisation of uptake/ elimination of metals on both a location (Omey Island, Dublin Bay and Dunmore East) and on a test species basis. A comparison was also completed in the same way as described above using the $t=18$ test locations and the $t=18$ control location (Omey Island).

\subsection{Statistics used for metals results}

Significant differences were tested by analysis of variance (ANOVA) using Microsoft ${ }^{\circledR}$ Excel Post Hoc Scheffe test to determine the nature of difference in dry weight metal concentrations between species for $\mathrm{Li}, \mathrm{Al}, \mathrm{K}, \mathrm{V}, \mathrm{Mn}, \mathrm{Fe}, \mathrm{As}, \mathrm{Sb}, \mathrm{Cd}$ and Zn. Summary ANOVA statistics for transplantation experiment including $F_{(2,6)}$ test statistic ( $\mathrm{F}$ Critical $=4.25)$, probability statistic $\mathrm{P}$ and nature of difference between species as derived from Post Hoc Scheffe tests. Significant differences in levels of manganese, cobalt and particularly for zinc were reported between mussels and oysters. Differences in the levels of lithium, aluminium, potassium and antimony (lower in gastropods than in either mussels or oysters) arsenic and cadmium (elevated in gastropods compared to mussels or oysters) were determined. Correlations were completed with S-Plus software between 23 element concentrations ( $\mathrm{mg} \mathrm{kg}^{-1}$ dry weight) and $\delta^{13} \mathrm{C}$ and $\delta^{15} \mathrm{~N}$ isotopes. Principle Components Analysis (Jeffers, 1978; Pielou, 1984) was based upon a correlation matrix to calculate only necessary Eigen values for three axes. Cluster Analysis (Pielou, 1984) was performed as Bray-Curtis with Single Linkage and plotted as \% similarity. Both analyses were performed in Biodiversity Pro 2 (McAleece et al., 1997).

\section{Results}

\subsection{Correlation analysis}

Concentrations ( $\mathrm{mg} \mathrm{kg}^{-1}$ dry weight) of 20 elements and for stable isotopes $(\%)$ in the test species are presented in Table 1 . For the purposes of further assessment concentration and stable isotope data were subdivided into five classifications, as follows, (1) Mussels- Mytilus edulis only (filter feeding), (2) Pacific OystersCrassostrea gigas only (filter feeding), (3) gastropod Nucella. lapillus only (predatory gastropod), (4) Mussels and oysters combined (as indicators of filter feeders), (5) Data from all three test species. Correlations were subsequently completed with S-Plus software between 23 element concentrations ( $\mathrm{mg} \mathrm{kg}^{-1}$ dry weight), $\delta^{13} \mathrm{C}$ and $\delta^{15} \mathrm{~N}$ for each of the above classifications allowing for the identification of strong positive and/or negative correlations between elements, between species (individual and combinations) and between locations. Significant correlations found were cadmium in $N$. lapillus and $\delta^{13} \mathrm{C}(r=-0.60)$ and $\delta^{15} \mathrm{~N}(r=-0.65)$, lithium in $N$. lapillus and $\delta^{13} \mathrm{C}(r=0.81)$ and $\delta^{15} \mathrm{~N}(r=0.82)$, arsenic in $N$. lapillus and $\delta^{13} \mathrm{C}(r=0.81)$ and $\delta^{15} \mathrm{~N}(r=0.82)$. Concentrations of cadmium and arsenic in all species from all locations are presented in Fig. 1.

Table 1

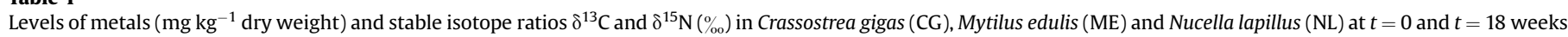
in Galway Bay (GB), Dublin Bay (DB), Dunmore East (DE) and Omey Island (OI).

\begin{tabular}{|c|c|c|c|c|c|c|c|c|c|c|c|c|}
\hline Location & $\begin{array}{l}\text { Galway } \\
(t=0 \mathrm{wks})\end{array}$ & Dublin Bay & $\begin{array}{l}\text { Dunmore } \\
\text { East }\end{array}$ & Omey Island & $\begin{array}{l}\text { Galway } \\
(t=0 \text { wks })\end{array}$ & Dublin Bay & $\begin{array}{l}\text { Dunmore } \\
\text { East }\end{array}$ & Omey Island & $\begin{array}{l}\text { Omey } \\
(t=0 \text { wsks })\end{array}$ & Dublin Bay & $\begin{array}{l}\text { Dunmore } \\
\text { East }\end{array}$ & Omey Island \\
\hline Species & CG & CG & CG & CG & ME & ME & ME & ME & $\mathrm{NL}$ & $\mathrm{NL}$ & $\mathrm{NL}$ & $\mathrm{NL}$ \\
\hline Dry wt\% & 24.4 & 21.2 & 21.8 & 22.1 & 21.9 & 20.3 & 21.1 & 24.79 & 30.1 & 37.2 & 36.4 & 36.4 \\
\hline $\mathrm{d}^{13} \mathrm{C}$ & -20.1 & -20.6 & -18.1 & -17.9 & -18 & -18.2 & -18.8 & -20.5 & -19.5 & -16.9 & -17.3 & -17 \\
\hline $\mathrm{d}^{15} \mathrm{~N}$ & 8.6 & 9.8 & 9 & 9 & 9.3 & 7.8 & 7.6 & 9.1 & 9.9 & 10.8 & 9.4 & 10.3 \\
\hline Li ICP & 0.67 & 0.72 & 0.67 & 0.69 & 0.54 & 0.68 & 0.81 & 0.55 & 0.56 & 0.29 & 0.29 & 0.29 \\
\hline $\mathrm{Na} I C P$ & 11,033 & 11,435 & 11,826 & 14,859 & 15,117 & 17,495 & 15,945 & 9728 & 18,501 & 6576 & 6415 & 6839 \\
\hline Mg ICP & 2132 & 2310 & 2133 & 2611 & 2696 & 3153 & 2746 & 1757 & 5541 & 2305 & 2068 & 2992 \\
\hline $\mathrm{Al} \mathrm{ICP}$ & 111 & 148 & 133 & 81.3 & 39.7 & 93.3 & 201 & 133 & 33.3 & 31 & 28.9 & 21.2 \\
\hline P ICP & 4761 & 7320 & 6301 & 5357 & 6944 & 5050 & 5318 & 5595 & 3871 & 5037 & 4873 & 4592 \\
\hline K ICP & 10,110 & 11,150 & 10,266 & 11,618 & 11,569 & 11,370 & 10,460 & 9866 & 6424 & 8784 & 8641 & 8416 \\
\hline Ca ICP & 33,549 & 13,910 & 2525 & 25,827 & 1263 & 3119 & 3948 & 1856 & 35,042 & 3296 & 3151 & 5226 \\
\hline V ICP & 1.05 & 1.21 & 0.88 & 1.29 & 1.11 & 1.59 & 1.41 & 0.95 & 0.52 & 0.88 & 0.61 & 0.88 \\
\hline $\mathrm{Cr}$ ICP & 1.7 & 0.79 & 0.99 & 1.09 & 1.24 & 0.98 & 1.51 & 0.71 & 2.26 & 0.65 & 1 & 0.88 \\
\hline Mn ICP & 21.3 & 47.1 & 29 & 31.8 & 4.64 & 9.02 & 13.4 & 12.1 & 10.6 & 13.8 & 11.4 & 9.5 \\
\hline Fe ICP & 254 & 188 & 191 & 175 & 29.8 & 152 & 261 & 113 & 124 & 56.6 & 55.5 & 46 \\
\hline $\mathrm{Ni}$ ICP & 1.58 & 0.81 & 1.03 & 1.21 & 1.56 & 1.43 & 1.47 & 0.88 & 2.57 & 0.51 & 0.53 & 0.75 \\
\hline Co ICP & 0.49 & 0.52 & 0.48 & 0.46 & 0.67 & 0.62 & 0.88 & 0.54 & 0.51 & 0.47 & 0.39 & 0.42 \\
\hline $\mathrm{Cu}$ ICP & 20.6 & 72.7 & 282 & 40.3 & 7.7 & 8.29 & 14.1 & 5.82 & 30.6 & 15.9 & 46.5 & 23.3 \\
\hline As ICP & 16.6 & 9.5 & 20.7 & 17.3 & 10.5 & 11.6 & 17.4 & 6.68 & 71.2 & 42.2 & 39.4 & 38.4 \\
\hline Sr ICP & 84.2 & 47 & 19.2 & 73.8 & 18.9 & 33 & 29.8 & 19.9 & 147 & 23.7 & 21.2 & 31.7 \\
\hline Mo ICP & 1.85 & 0.84 & 0.83 & 1.27 & 1 & 2.64 & 1.73 & 1.8 & 0.56 & 1.23 & 0.63 & 0.76 \\
\hline Sb ICP & 0.28 & 0.28 & 0.27 & 0.27 & 0.39 & 0.31 & 0.31 & 0.25 & 0.21 & 0.16 & 0.17 & 0.16 \\
\hline $\mathrm{Pb}$ ICP & 1.2 & 1.65 & 1.51 & 0.74 & 1.01 & 1.22 & 4.42 & 2.45 & 0.54 & 1.05 & 1.32 & 0.54 \\
\hline U ICP & 0.46 & 0.44 & 0.51 & 0.56 & 0.54 & 0.49 & 0.46 & 0.32 & 0.38 & 0.32 & 0.35 & 0.34 \\
\hline Hg - FIM; & 0.13 & 0.1 & 0.23 & 0.13 & 0.15 & 0.12 & 0.18 & 0.06 & 0.18 & 0.16 & 0.28 & 0.18 \\
\hline Cd-GFAA & 1.49 & 1.14 & 1.37 & 1.17 & 1.77 & 1.05 & 1.43 & 0.67 & 34.1 & 23.7 & 24.1 & 22.3 \\
\hline Zn-FAA & 673 & 786 & 1466 & 791 & 120 & 148 & 251 & 118 & 163 & 204 & 238 & 172 \\
\hline
\end{tabular}

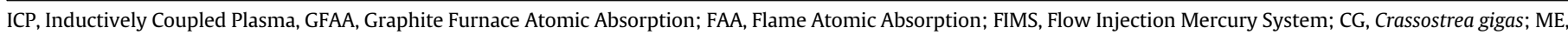
Mytilus edulis; NL, Nucella lapillus. 
3.2. Trends in element uptake/elimination compared to $t=0$ and control (Omey Island $t=18$ )

Graphical data detailing trends in element uptake/elimination in all species [(a) Mytilus edulis, (b) Crassostrea gigas and (c) Nucella lapillus] at both sites Dunmore East, Dublin Bay $(t=18)$ compared to control Omey Island $(t=18)$ is presented in Fig. 2. Summary ANOVA statistics for transplantation experiment including $F$ test statistic (F Critical $=4.252$ and $6 \mathrm{df}$ ), probability statistic $\mathrm{P}$ and nature of difference between species as derived from Post Hoc Scheffe tests is presented in Table 2 . This shows significant differences in metal uptake/elimination between the filter feeding organisms' C. gigas and M. edulis and the predator $N$. lapillus.

\subsection{Principal components and cluster analysis}

Principle Components Analysis (Jeffers, 1978; Pielou, 1984) is presented in Fig. 3 and was based upon a correlation matrix to calculate only necessary Eigen values for three axes. Cluster Analysis (Pielou, 1984) was performed as Bray-Curtis with Single Linkage and plotted as \% similarity. This is demonstrated in Fig. 4.
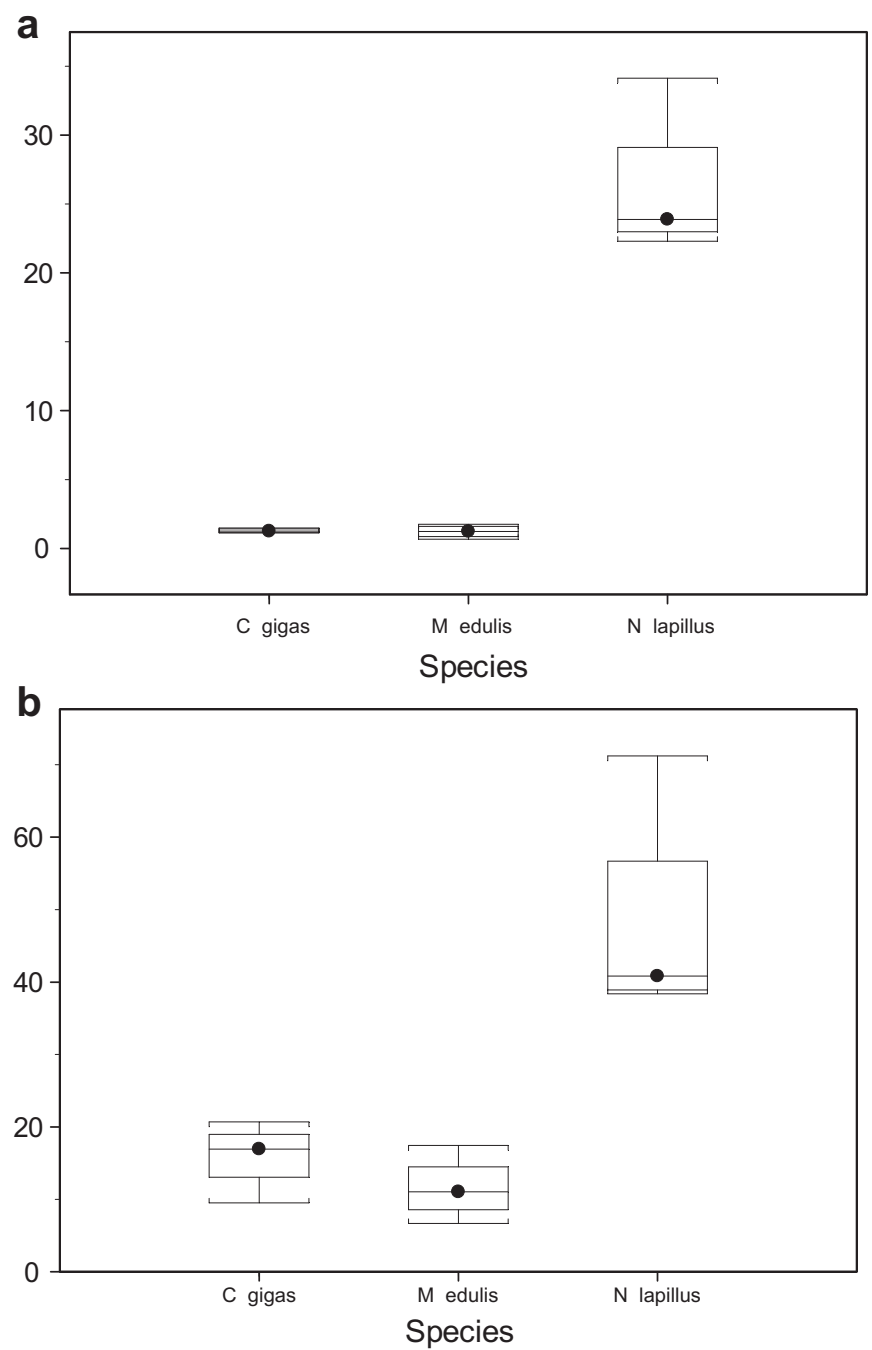

Fig. 1. (a) Concentrations of cadmium (Cd) and (b) arsenic (As) in the caged species, Crassostrea gigas, Mytilus edulis and Nucella lapillus species from all sites after 18 weeks exposure. Concentration data from each species was pooled for three sites and summed.
Both analyses were performed in Biodiversity Pro 2 (McAleece et al., 1997). In both Principle Components Analysis (PCA) (Fig. 3) and Cluster Analysis (CA) (Fig. 4) samples were grouped primarily by species; Crassostrea gigas, Mytilus edulis and Nucella lapillus. Samples of $N$. lapillus clustered closest together and separated furthest from other samples. Signals of site were present in the analysis. For all 3 species, samples showed the same site ordering along Axis 1 of the PCA within their respective clusters. Samples collected at the site of origin at $t=0$, showed the lowest score along the axis, followed in all three cases, by Omey Island, Dublin Port and finally Dunmore East.

\subsection{Stable isotope analysis}

Stable isotope ratios for all species at each of the four sites analysed are presented in Table 1 . Stable isotope profiling $\left(\delta^{13} \mathrm{C}\right.$ versus $\delta^{15} \mathrm{~N}$ ) in Crassostrea gigas, Mytilus edulis and Nucella lapillus at $t=0$ and $t=18$ weeks at all three coastal locations is demonstrated in Fig. 5. It is demonstrated that N. lapillus at all locations occupies a higher trophic status than the other two filter feeding organisms. This is evident from the higher $\delta^{15} \mathrm{~N}$ signals. $\delta^{13} \mathrm{C}$ signals for each of the organisms in particular $C$. gigas, indicate that sources of food and potentially salinity were different at each site Different sources of food could be an important factor contributing to differences in metal uptake at all three sites.

\section{Discussion}

\subsection{Overall observations on metals concentrations between $t=0$ and $t=18$ sample}

Cadmium levels were found to be more elevated in both resident gastropods $(t=0)$ and in gastropods transplanted to each of the test locations than in either transplanted mussels or oysters (see Fig. 1). Levels of cadmium are raised in the initial ( $t=0)$ sample and are still elevated in ( $t=18$ weeks) at Omey Island. Cadmium levels at Omey Island would be expected to be low therefore in the absence of additional supporting data it is unclear whether results suggest that the gastropod, Nucella lapillus, has a greater capacity to accumulate cadmium in their tissues or may have a lower capacity to eliminate the metal than the other species. Abdullagh and Ireland (1986) have reported that rates of cadmium uptake after exposure to cadmium were inconsistent in $N$. lapillus and not related to degree of site contamination. Exposure to cadmium is responsible for metallothionein induction in N. lapillus, and metalrich granules (MRG) have also been shown to be involved in cadmium storage in detoxified form (Leung and Furness, 2001a; Cheung et al., 2006). Strong positive/negative correlations can indicate that parameters are closely associated, and in the case of metals that they may have similar assimilation and/or elimination mechanisms. In the case of filter feeding organisms (oysters and mussels) strong correlations in opposite directions may indicate that mechanisms for the assimilation/elimination of metals may differ within species. Strong correlations between stable isotope parameters and individual metals may indicate dietary related assimilation of metals. Correlations between cadmium levels in $N$. lapillus and $\delta^{13} \mathrm{C}(r=-0.60)$ and $\delta^{15} \mathrm{~N}(r=-0.65)$ suggested dietary influences in cadmium uptake in the species, however this should be further investigated (as discussed in detail below) due to the small site/sample number $(n=4)$ available.

Levels of zinc were more elevated in oysters than observed in either mussels or in the gastropods. Zinc levels were also found to be more elevated for each of the test species located in Dunmore East (see Fig. 2). The capacity within the oysters to accumulate higher concentrations of zinc and (copper) in oysters is primarily 

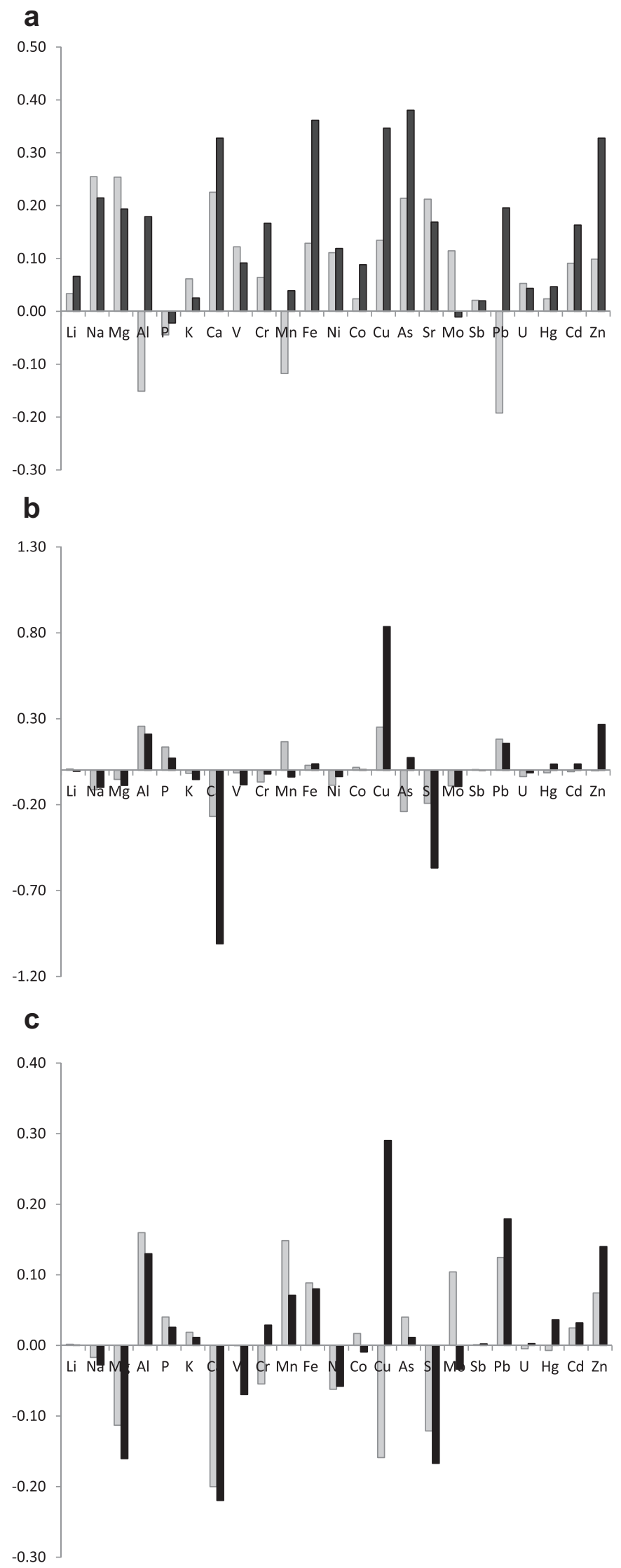

Fig. 2. Graphical data detailing trends $\left[t_{18}-t_{18 \text { control }}\right.$ at Omey Island] in element uptake/elimination in all species [ (a) M. edulis, (b) C. gigas and (c) N. lapillus at both related to the oysters' high pumping rate. George et al. (1978) report that based on observations of copper in the oyster Ostrea edulis relative to mussels, may be attributable to bonding to sulphur within haemocytes. Such haemocytes are typically present in all oysters (Roesijadi, 1996). This mechanism may be responsible for the strong correlation between silver and copper concentrations as reported by Daskalakis (1996). Elevated levels of zinc have also been reported to be related to changes in salinity. Blackmore and Wang (2003b) compared the biokinetics of metals in the green mussel Perna viridis from two sites of contrasting salinity. Concentrations of metals (cadmium, chromium, selenium and zinc) were 1.2-6.4 times greater in mussels collected from the low salinity site compared to those from the high salinity site. The authors suggest that $\mathrm{Cr}(\mathrm{VI})$ and $\mathrm{Se}(\mathrm{IV})$, which are present as anions in solution are not affected by chloride complexation, thus behave similarly to cadmium and zinc in that their uptake from the dissolved phase increased with decreased salinity and dissolved speciation was not the only factor to affect metal uptake from solution by the mussels. However salinity data was not collected from each of the three locations in this present study.

Levels of lithium were found to be lower in Nucella lapillus than in either Crassostrea gigas or Mytilus edulis. Manganese levels were lower in C. gigas and N. lapillus than in M. edulis. Levels of iron were lower in $N$. lapillus transplanted to the three test sites than in other species with the exception of $M$. edulis at the $t=0$ reference site. Nickel was lower in $N$. lapillus transplanted to the three test sites than in other transplanted species. Cobalt was found to be more elevated in M. edulis than in the other test species.

Copper levels were more elevated in each of the test species transplanted to both Dublin Bay and Dunmore East indicating increased concentrations of these metals at these two more industrialised locations (see Fig. 2). Elevated levels of copper (290 $\mathrm{mg} \mathrm{kg}^{-1}$ ) have been reported in the sediment at this site (Enterprise Ireland, unpublished data). Similarly lead (with the exception of mussels from Omey Island $t=18$ ) was more elevated in Dunmore East and Dublin Bay than in Omey Island. Elevated levels of lead (62.2 and $53.4 \mathrm{mg} \mathrm{kg}^{-1}$ respectively) have been reported in $<2$ mm sediment fraction at these two sites (Giltrap, 2008). Mercury was raised in each of the species transplanted to Dunmore East compared to the other sites. Arsenic levels were higher in Nucella lapillus (range $38.4-71.2 \mathrm{mg} \mathrm{kg}^{-1} \mathrm{dry}$ weight) than in either mussels or oysters at other test locations while antimony concentrations were found to be lower in gastropods than in mussels or oysters.

O'Leary and Breen (1997) reported metal levels in seven species of mollusc and in seaweed from the Shannon Estuary. Overall Mytilus edulis species showed broadly similar concentrations of metals in sites in the present study compared to the Shannon Estuary study however Dunmore East showed elevated levels of copper and iron compared to the Shannon study. Levels of iron and copper were broadly similar when comparing Nucella lapillus in both the Shannon Estuary study and this present study. The assessment criteria set by the Oslo and Paris Commission namely background assessment criteria (BAC) and environmental assessment criteria (EAC) for cadmium, mercury and lead in mussels and oysters can be used to indicate water quality. Good ecological status of the water quality would be indicated if levels of these metals were below BAC. If the EAC is exceeded this could potentially give rise to an undesirable toxicological effect. In $M$. edulis at all three sites studied, cadmium, mercury and lead all exceeded BAC but did not exceed EAC. In Crassostrea gigas for all three metals all sites

Dunmore East (DE: $\mathbf{a})$ and Dublin Bay (DB: $)$ ), compared to the control Omey Island $t=18$. The $\log (\mathrm{x}+1)$ of the metal concentration was subtracted in the $t=18$ week test sites from the $t=18$ control in order to scale down the metal trends. 
Table 2

Summary ANOVA statistics for transplantation experiment including $\mathrm{F}$ test statistic (F Critical $=4.252$ and $6 \mathrm{df}$ ), probability statistic $P$ and nature of difference between species as derived from Post Hoc Scheffe tests.

\begin{tabular}{|c|c|c|c|c|c|c|}
\hline \multirow[t]{2}{*}{ Metal } & \multirow[t]{2}{*}{ Significance } & $\mathrm{F}$ test & \multirow[t]{2}{*}{ Probability } & \multirow[t]{2}{*}{$\mathrm{ME}-\mathrm{CG}$} & \multirow[t]{2}{*}{$\mathrm{NL}-\mathrm{CG}$} & \multirow[t]{2}{*}{$\mathrm{NL}-\mathrm{ME}$} \\
\hline & & $\begin{array}{l}\text { (F crit. } 4.25 \\
9.2 \mathrm{df})\end{array}$ & & & & \\
\hline li & $*$ & 11.05 & 0.0038 & 0.85 & 0.006 & 0.014 \\
\hline $\mathrm{Na}$ & & 1.5 & & & & \\
\hline $\mathrm{Mg}$ & & 0.92 & & & & \\
\hline al & * & 5.78 & 0.024 & 0.99 & 0.046 & 0.049 \\
\hline $\mathrm{P}$ & & 2.807 & & & & \\
\hline $\mathrm{K}$ & * & 12.6 & 0.0025 & 0.99 & 0.006 & 0.005 \\
\hline $\mathrm{Ca}$ & & 1.88 & & & & \\
\hline V & $*$ & 6.2 & 0.0203 & 0.625 & 0.103 & 0.02 \\
\hline $\mathrm{Cr}$ & & 0.02 & & & & \\
\hline Mn & $*$ & 13.998 & 0.0017 & 0.0035 & 0.0056 & 0.94 \\
\hline $\mathrm{Fe}$ & $*$ & 4.405 & 0.046 & 0.4 & 0.046 & 0.347 \\
\hline $\mathrm{Ni}$ & & 0.16 & & & & \\
\hline Co & $*$ & 7.38 & 0.0127 & 0.046 & 0.82 & 0.018 \\
\hline $\mathrm{Cu}$ & & 2.03 & & & & \\
\hline As & $*$ & 15.899 & 0.001 & 0.812 & 0.004 & 0.002 \\
\hline $\mathrm{Sr}$ & & 0.808 & & & & \\
\hline $\mathrm{pb}$ & & 2.29 & & & & \\
\hline $\mathrm{Hg}$ & & 1.91 & & & & \\
\hline $\mathrm{Cd}$ & $*$ & 82.26 & 0.0001 & 0.999 & 0.00000562 & 0.0000055 \\
\hline $\mathrm{Zn}$ & $*$ & 16.64 & 0.0009 & 0.0021 & 0.0029 & 0.97 \\
\hline
\end{tabular}

Grey shaded areas in Table 2 represent significance $p \leq 0.05$.

* Significant difference denoted.

were below EAC, with cadmium below BAC for all three sites. Mercury was elevated above BAC for both Dunmore East and Omey Island and all sites showed to be above BAC for lead. Overall, all levels were lower than EAC and therefore there is no potential toxic effect expected at any of these sites.

It has been recommended that growth rate of the bivalves be monitored as an additional tool when examining differences in metal concentrations in bivalves from different locations. Wang and Fisher (1997) suggested that the growth rate is needed to predict the metal concentration and allometry of metal accumulation in the mussel Mytilus edulis, especially in the case of smaller mussels. For future studies it is recommended that growth rates of organisms be studied as an additional tool especially in metal impacted areas.

A previous history of environmental exposure of a population to metals itself may result in changes within that populations metal handling physiology. Prior metal exposure may induce specific metal detoxification processes or physiological and biochemical changes that can subsequently affect the uptake of metals (Wang and Rainbow, 2005). Shi and Wang (2004) compared the cadmium biokinetics in clams Ruditapes philippinarum from a previously contaminated site and a "clean" site and found that the contaminated clam population had a higher metallothionein (MT) concentration compared to the uncontaminated population. No significant difference in the dissolved uptake rate constants, efflux rate constants and the clearance rates of the two were observed between the populations and the contaminated clam population had significantly higher cadmium and zinc AEs compared to the uncontaminated population. The authors suggest that AE differences may account for the higher cadmium and zinc tissue concentrations in the clams from the contaminated site and may suggest the presence of a "positive feedback" mechanism. Others studies (e.g. Rainbow et al., 1999) on amphipods (Orchestia gammarellus) and crabs (Carcinus maenas and Pachygrapsus marmoratus) did not suggest such positive feedback. Mussels rapidly accumulate heavy metals and can carry out depuration when animals are transplanted to clean locations or when environmental concentrations of contaminants decline (Okazaki and Panietz, 1981). It has been reported that despite depuration, detoxification and the potential for metals isolation, that heavy metals negatively affect growth of mussels and other bivalves (Manley et al., 1984; Rainbow, 1995; Din and Ahamad, 1995).

The above findings with respect to biotic accumulation of elevated metals levels at test sites in both Dunmore East and Dublin suggest rapid accumulation of bioavailable metals from the surrounding environment and provide a valid tool for biomonitoring metal impacted areas as previously reported by Regoli and Orlando (1994), Regoli et al. (2004).

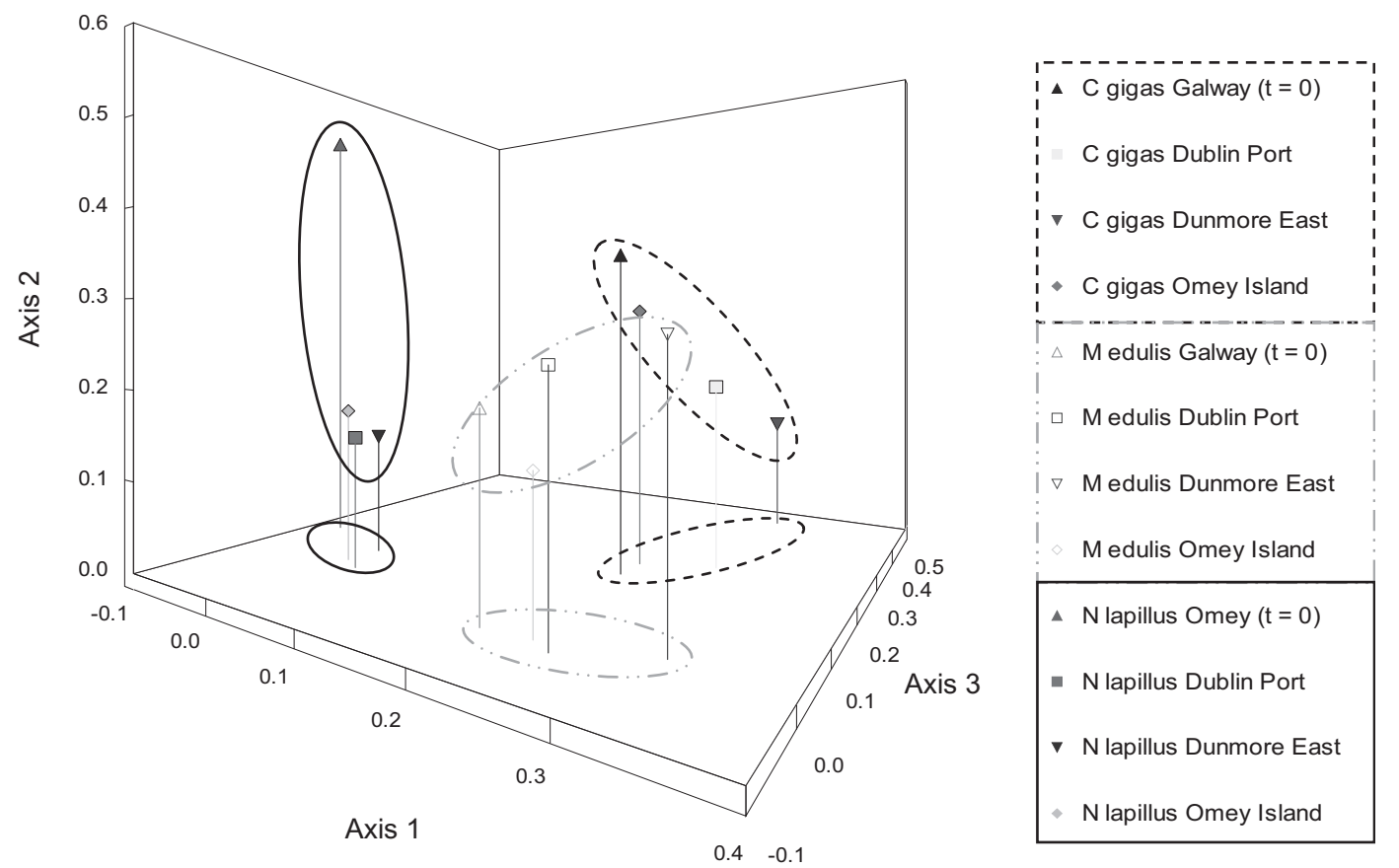

Fig. 3. Principle Components Analysis Axis 1, 2 and 3 with clusters by species indicated (Biodiversity Pro 2). 


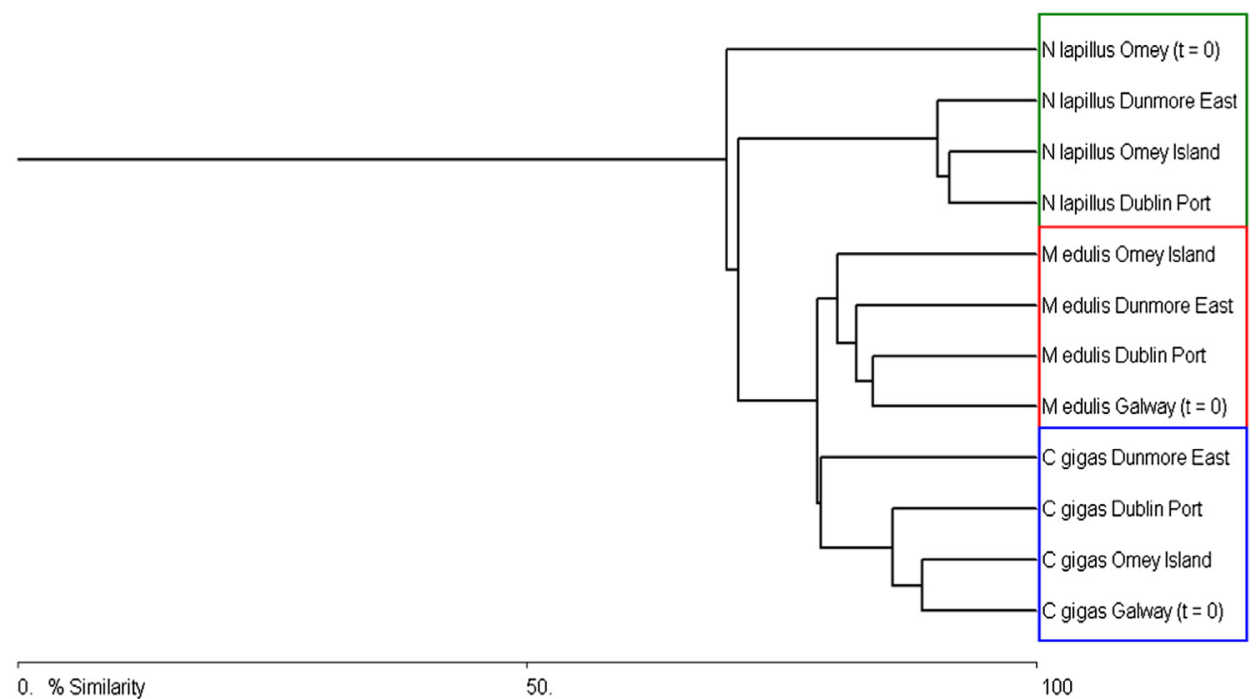

Fig. 4. Bray-Curtis Cluster Analysis (single Linkage) with clusters indicated (Biodiversity Pro 2).

4.2. Metal concentrations in Mytilus edulis between test and control locations $(t=18)$

Compared to the control site at Omey Island at $t=18$ weeks, higher levels of elements were observed at Dunmore East compared to the Dublin Bay site. Dublin Bay showed elevated levels of sodium, magnesium and strontium [17,495, 3153, $33 \mathrm{mg} \mathrm{kg}^{-1}$ respectively] whereas Dunmore East showed elevated levels of, aluminium, calcium, iron, cobalt, copper, arsenic, lead, cadmium and zinc $\left[201,3948,0.88,14,17,4.42,1.43,251 \mathrm{mg} \mathrm{kg}^{-1}\right.$ respectively]. In general levels of elements in mussels transplanted to Dunmore East were found to be higher than in those

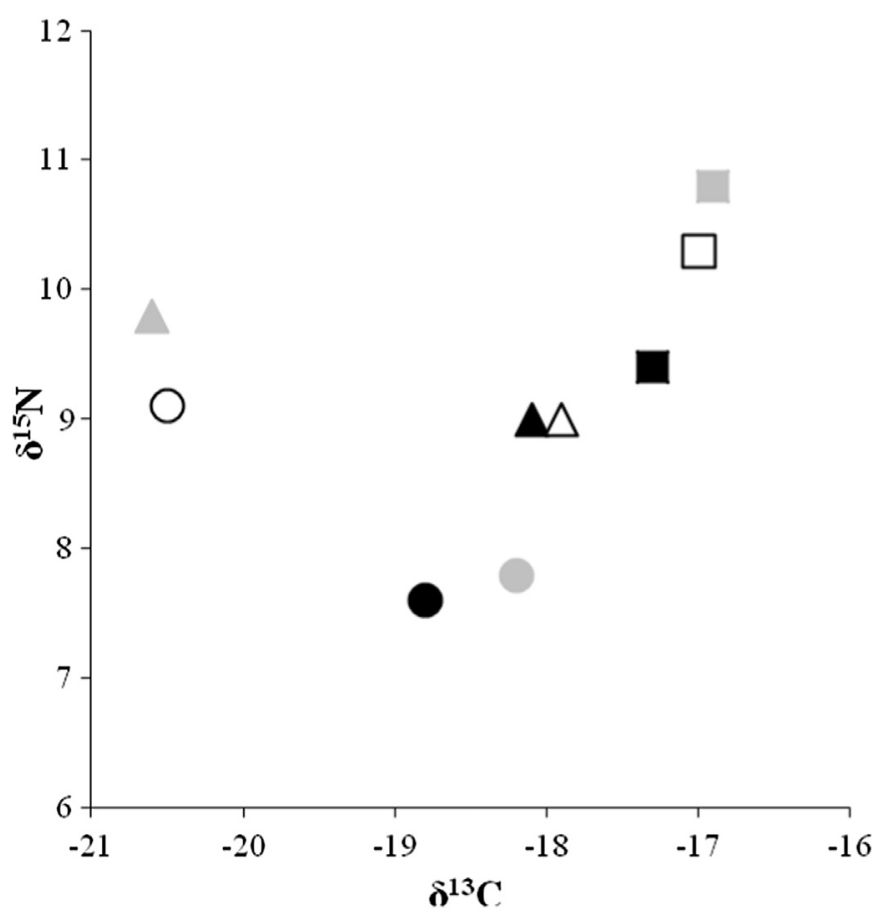

Fig. 5. $\delta^{13} \mathrm{C}$ versus $\delta^{15} \mathrm{~N}$ stable isotope ratios (\%) in Crassostrea gigas (CG: $\Delta$ ), Mytilus edulis (ME: $\mathrm{O}$ ) and Nucella lapillus (NL: $\square$ ) at Dublin Bay (DB: ), Dunmore East (DE: $\mathbf{a})$ and Omey Island (OI: $\square) t=18$ weeks. transplanted to other locations. Lead was lower in Dublin Bay transplanted mussels compared to the control location. Raftopoulou and Dimitriadis, 2011 reported an antagonistic effect of the essential metal copper against the non-essential metal mercury in the digestive gland of Mytilus galloprovincialis supporting the protective role of copper against mercury toxicity. A similar pattern is shown in both sites Mytilus edulis in this present study in Fig. 2.

\subsection{Metal concentrations in Crassostrea gigas between locations}

Concentration levels for the majority of metals were broadly similar in oysters transplanted to all test locations. Dunmore East showed more elevated levels of aluminium, copper, zinc, cadmium, mercury and arsenic [133, 282, 1466, 1.37, 0.23, $21 \mathrm{mg} \mathrm{kg}^{-1}$ respectively] with lead and copper elevated at both sites in the oysters. Sodium, calcium and strontium levels were lower at both sites compared to the control.

\subsection{Metal concentrations in Nucella lapillus between locations}

Stable isotope $\left(\delta^{15} \mathrm{~N}\right)$ data suggest that Nucella lapillus occupy a higher trophic level than either Mytilus edulis or Crassostrea gigas (see Fig. 5) and thus accumulation of metals may potentially result as a consequence of its predatory nature. Dunmore East showed highest levels of elements namely copper, lead, mercury, cadmium and zinc [47, 1.32, 0.28, 24.09 and $238 \mathrm{mg} \mathrm{kg}^{-1}$ respectively] while elevated levels of lead, cadmium and zinc [1.05, 23.67, $204 \mathrm{mg}$ $\mathrm{kg}^{-1}$ respectively] were also show at the Dublin Bay site. Levels of copper in $N$. lapillus from the Dublin Bay site were lower than at control site. Levels of lithium were found to be lower in gastropods than in either oysters or mussels with strong correlations between lithium and $\delta^{13} \mathrm{C}(r=0.81)$ and $\delta^{15} \mathrm{~N}(r=0.82)$ indicating potential dietary assimilation influences. Arsenic levels were found to be higher in gastropods (range $38.4-71.2 \mathrm{mg} \mathrm{kg}^{-1}$ dry weight) than in either mussels or oysters at other test locations with strong correlations to both $\delta^{13} \mathrm{C}(r=0.81)$ and $\delta^{15} \mathrm{~N}(r=0.82)$. Raised imposex indices (Giltrap et al., 2009) were determined in gastropods from Dunmore East. While elevated organotin levels have been found at this location, it may be of significance that a number of other metals are elevated in gastropods transplanted to Dunmore East. 


\subsection{Metal and stable isotopes correlations in classification groups}

As previously discussed, stable isotopes provide a mechanism whereby dietary assimilation of nutrients can be tracked and where assimilation of contaminants can be modelled. A full discussion on the use of stable isotopes to trace nutrient assimilation in these caging studies is previously described in Giltrap et al. (2009), while the application of stable isotopes in tracing metals assimilation/ elimination is further discussed below.

A substantial dataset containing concentration data from a total of 20 elements, 2 stable isotope and five biota classifications was available and a large correlations dataset was established. However the discriminatory power in such correlations was reduced based on the low number of samples (3 sites with 1 replicate each). Additionally due to the complex/dynamic nature of test sites it was deemed inappropriate to utilise SI techniques to identify potential dietary/trophic level correlations with this dataset. With additional discriminatory power in the form of an increased number of samples and establishment of the level of potential analytical errors associated with singlicate sampling SI techniques may prove to be valuable in further elucidating the influence of diet/trophic status in trace metal assimilation/elimination.

\subsection{Principle components analysis and cluster analysis}

The predatory gastropod Nucella lapillus from all sites clustered closest together and separated furthest from other samples demonstrating their predatory nature. Site differences were evident in the PCA analysis. For all 3 species, samples showed the same site ordering along Axis 1 of the PCA within their respective clusters. Samples collected at the site of origin at $t=0$, showed the lowest score along the axis, followed in all three cases, by Omey Island, Dublin Port and finally Dunmore East at $t=18$. Results of Bray Curtis Cluster Analysis suggest that metabolism/absorption and the accumulation of metals in tissues is species specific. Both suspension feeding organisms (Crassostrea gigas and Mytilus edulis) clearly show similarities in clusters but also show some differences possibly due to variation in pumping rates. These filter feeding organisms cluster away from the predatory gastropod $N$. lapillus which obtains most of its food from feeding on whole tissues and hence biomagnifying some contaminants. Clearly, tissue loadings of chemicals from different species are not comparable. Also, within species results indicate that there is a site influence upon tissue concentrations.

\section{Conclusion}

Rapid biotic accumulation of metals was demonstrated in the test species, especially in both Dunmore East and Dublin suggesting the caging study as described is a valid tool for biomonitoring metal impacted areas. Application of the SI technique to describe carbon and nitrogen assimilation/elimination in the test species has been demonstrated. It has been shown that the caging study is suitable for the deployment of indicator species to potential hotspot locations or where resident species may be absent. Further to this, the metals and stable isotopes datasets derived during this study are of significant value in supporting other biological effects as previously reported by Giltrap et al. (2009) (i.e. imposex in the gastropod Nucella lapillus and shell thickening in Crassostrea gigas).

\section{Acknowledgements}

We thank the Eastern Regional Fisheries Board and Sean Cullen and Archie Donovan of the Geological Survey of Ireland for sampling assistance. We also thank the Dublin Port Authority and the Dunmore East Harbour Authority for their cooperation, Iarfhaidh Connellan for supplying the mussels and oysters, and Paschal Whelan for providing support at Omey Island. Funding for this research was provided by the Technology Sector Research: Strand III: Core Research Strengths and from Dublin Institute of Technology's Capacity Building Scheme (CaBS) for Strategic Research.

\section{References}

Abdullagh, A.M., Ireland, M.P., 1986. Cadmium content, accumulation and toxicity in dog whelks collected around the Welsh coastline. Marine Pollution Bulletin 17 (12), 557-561.

Amiard, J.C., Amiard-Triquet, C., Barka, S., Pellerin, J., Rainbowd, P.S., 2006. Review. Metallothioneins in aquatic invertebrates: their role in metal detoxification and their use as biomarkers. Aquatic Toxicology 76, 160-202.

Blackmore, G., Wang, W.-X., 2003a. Variations of metal accumulation in marine mussels at different local and global scales. Environmental Toxicology and Chemistry 22, 388-395.

Blackmore, G., Wang, W.X., 2003b. Inter-population differences in Cd, Cr, Se, and Zn accumulation by the green mussel Perna viridis acclimated at different salinities. Aquatic Toxicology 62, 205-218.

Bouquegneau, J.M., Martoja, M., 1982. Copper content and its degree of complexation in four marine gastropods. Data concerning cadmium and zinc. Oceanologica Acta Paris 5 (2), 219-228.

Bjerregaard, P., Depledge, M.H., 1994. Cadmium accumulation in Littorina littorea, Mytilus edulis, and Carcinus maenas: the influence of salinity and calcium ion concentrations. Marine Biology 119, 385-395.

Cheung, M.-S., Fok, E.M.W., Ng, T.Y.T., Yen, Y.-F., Wang, W.-X., 2006. Subcellular cadmium distribution, accumulation and toxicity in a predatory gastropod, Thais clavigera, fed different prey. Environmental Toxicology and Chemistry 25, 174-181.

Chuang, C.Y., Wang, W.-X., 2006. Co-transport of metal complexes by the green mussel Perna viridis. Environmental Science and Technology 40, 4523-4527.

Cossa, D., 1989. A review of the use of Mytilus spp. as quantitative indicators of cadmium and mercury contamination in coastal water. Oceanologica Acta 12, 417-432.

Daskalakis, K.D., 1996. Variability of metal concentrations in oyster tissue and implications to biomonitoring. Marine Pollution Bulletin 32, 794-801.

DeNiro, M.J., Epstein, S., 1978. Influence of diet on the distribution of carbon isotopes in animals. Geochimica et Cosmochimica Acta 42, 495-506.

Din, Z.B., Ahamad, A., 1995. Changes in the scope for growth of blood cockles (Anadara granosa) exposed to industrial discharge. Marine Pollution Bulletin 31, $4-12$.

George, S.G., Pirie, B.J.S., Cheyne, A.R., Coombs, T.L., Grant, P.T., 1978. Detoxication of metals by marine bivalves: an ultrastructural study of the compartmentation of copper and zinc in the oyster Ostrea edulis. Marine Biology 45, 147-156.

Giltrap M., 2008. An integrated approach to the toxicity evaluation of Irish marine sediment: chemical assessment, $\mathrm{PhD}$ thesis.

Giltrap, M., Macken, A., Davoren, M., Minchin, D., McGovern, E., Foley, B., Strand, J., McHugh, B., 2009. Use of caged Nucella lapillus and Crassostrea gigas to monitor tributyltin-induced bioeffects in Irish coastal waters. Environmental Toxicology and Chemistry 28, 1671-1678.

Goldberg, E.D., 1975. The mussel watch - a first step in global marine monitoring. Marine Pollution Bulletin 6, 111.

Jeffers, J.N.R., 1978. An Introduction to Systems Analysis with Ecological Applications. Arnold, London.

Lee, B.-G., Luoma, S.N., 1998. Influence of microalgal biomass on absorption efficiency of $\mathrm{Cd}, \mathrm{Cr}$, and $\mathrm{Zn}$ by two bivalves from San Francisco. Limnology and Oceanography 43, 1455-1466.

Lee, B.G., Wallace, W.G., Luoma, S.N., 1998. Uptake and loss kinetics of Cd, Cr, and Zn in the bivlaves Potamocorbula amurensis and Macoma bathicar: effects of size and salinity. Marine Ecology Progress Series 175, 177-189.

Leung, K.M.Y., Furness, R.W., 2001a. Survival, growth, metallothionein and glycogen levels of Nucella lapillus (L.) exposed to sub-chronic cadmium stress: the influence of nutritional state and prey type. Marine Environmental Research 52, 173-194.

Manley, A.R., Gruffydd, L.I.D., Almada-Villela, P.C., 1984. The effect of copper and zinc on the shell growth of Mytilus edulis measured by a laser diffraction technique. The Marine Biological Association of the United Kingdom 64 (2), 417-427.

Marsden, I.D., Rainbow, P.S., 2004. Does the accumulation of trace metals in crustaceans affect their ecology - the amphipod example? Journal of Experimental Marine Biology and Ecology 300, 343-371.

McAleece, N., Lambshead, P.J.D., Paterson, G.L.J., Gage, J.D., 1997. Biodiversity Pro. A Program Research for Analysing Ecological Data. The Natural History Museum, London and the Scottish Association for Marine Science, Oban. http:// www.sams.ac.uk/.

Minagawa, M., Wada, E., 1984. Stepwise enrichment of ${ }^{15} \mathrm{~N}$ along food chains: further evidence and the relation between ${ }^{15} \mathrm{~N}$ and animal age. Geochimica et Cosmochimica Acta 48, 1135-1140.

Okazaki, R.K., Panietz, M.H., 1981. Depuration of twelve trace metals in tissues of the oysters Crassostrea gigas and Crassostrea virginica. Marine Biology 63, 113-120. 
O'Leary, C., Breen, J., 1997. Metal levels in seven species of mollusk and in seaweeds from the Shannon Estuary. Biology and Environment: Proceedings of the Royal Irish Academy 97 (2), 121-132.

Oslo and Paris Commission (OSPAR), 2005. Coordinated Environmental Monitoring Programme-Reference 2005-5. www.ospar.org.

Pan, J.F., Wang, W.-X., 2004. Differential uptake of dissolved and particulate organic carbon by the marine mussel Perna viridis. Limnology and Oceanography 49, 1980-1991.

Peterson, B.J., Fry, B., 1987. Stable isotopes in ecosystem studies. Annual Review of Ecology and Systematics 18, 293-320.

Pielou, E.C., 1984. The Interpretation of Ecological Data. Wiley, New York.

Post, N.L., 2002. Using stable isotopes to estimate trophic position: models, methods and assumptions. Ecology 83, 703-718.

Quintela, M., Barreiro, R., Ruiz, J.M., 2000. The use of Nucella lapillus (L.) transplanted in cages to monitor tributyltin (TBT) pollution. The Science of the Total Environment 247, 227-237.

Raftopoulou, E.K., Dimitriadis, V.K., 2011. Comparative study of the accumulation and detoxification of $\mathrm{Cu}$ (essential metal) and $\mathrm{Hg}$ (non essential metal) in the digestive gland and gills of mussels Mytilus galloprovincialis, using analytical and histochemical techniques. Chemosphere 83, 1155-1165.

Rainbow, P.S., Phillips, D.J.H., Depledge, M., 1990. The significance of trace metal concentrations in marine invertebrates. A need for laboratory investigation of accumulation strategies. Marine Pollution Bulletin 21, 321-324.

Rainbow, P.S., 1992. The accumulation by marine organisms of heavy metals and its significance marine environmental science/Haiyang Huanjing Kexue. Dalian 11 (1), 44-52.

Rainbow, P.S., 1995. Biomonitoring of heavy metal availability in the marine environment. Marine Pollution Bulletin 31, 183-192.

Rainbow, P.S., 1998. Phylogeny of trace metal accumulation in Crustaceans. In: Langston, W.J., Bebianno, M.J. (Eds.), Metal Metabolism in Aquatic Environments. Chapman and Hall, London, pp. 285-319.

Rainbow, P.S., Amiard-Triquet, C., Amiard, J.C., Smith, B.D., Best, S.L., Nassiri, Y., Langston, W.J., 1999. Trace metal uptake rates in crustaceans (amphipods and crabs) from - 278-coastal sites in NW Europe differentially enriched with trace metals. Marine Ecology Progress Series 183, 189-203.

Rainbow, P.S., 2002. Trace metal concentrations in aquatic invertebrates: why and so what? Environmental Pollution 120, 497-507.

Rainbow, P.S., 2007. Trace metal bioaccumulation: models, metabolic availability and toxicity. Environment International 33, 576-582.

Regoli, F., Frenzilli, G., Bocchetti, R., Annarumma, F., Scarcelli, V., Fattorini, D., Nigro, M., 2004. Time-course variations of oxyradical metabolism, DNA integrity and lysosomal stability in mussels, Mytilus galloprovincialis, during a field translocation experiment. Aquatic Toxicology 68, 167-178.
Regoli, F., Orlando, E., 1994. Accumulation and subcellurar distribution of metals ( $\mathrm{Cu}, \mathrm{Fe}, \mathrm{Mn}, \mathrm{Pb}$ and $\mathrm{Zn}$ ) in the Mediterranean mussels Mytilus galloprovincialis during a field transplant experiment. Marine Pollution Bulletin 28, 592-600.

Riveros, A., Zuniga, M., Larrain, A., 2003. Copper metallothionein-like proteins as exposure biomarker in native and transplanted intertidal populations of the mussel Perumyltilus purpuratus from San Jorge Bay, Antofagasta. Chilean Bulletin of Environmental Contamination and Toxicology 70, 233-241.

Roesijadi, G., 1993. Metallothioneins in metal regulation and toxicity in aquatic animals. Aquatic Toxicology 22, 81-114.

Roesijadi, G., 1996. Environmental factors: response to metals. In: Kennedy, V.S., et al. (Eds.), The Eastern Oyster. Crassostrea virginica Maryland Sea Grant, College Park, MD, pp. 515-537.

Romeo, M., Hoarau, P., Garrello, G., Gnassia-Barelli, M., Girard, J.P., 2003. Mussel transplantation and biomarkers as useful tools for assessing water quality in the NW. Mediterranean. Environmental Pollution 122, 369-378.

Rounick, J.S., Winterbourn, M.J., 1986. Stable carbon isotopes and carbon flow in ecosystems. BioScience 36, 171-177.

Shi, D., Wang, W.-X., 2004. Understanding the differences in Cd and Zn bioaccumulation and 6 subcellular storage among different populations of marine clams. Environmental Science and Technology 38 (7), 449-456.

Smith, A.J., Thain, J.E., Barry, J., 2006. Exploring the use of caged Nucella lapillus to monitor changes to TBT hotspots areas: a trial in the River Tyne estuary (UK). Marine Environmental Research 62, 149-163.

Strand, J., Larsen, M.M., Lockyer, C., 2005. Accumulation of organotin compounds and mercury in harbour porpoises (Phocoena phocoena) from the Danish waters and West Greenland. Science of the Total Environment 350 (1-3), 59-71.

Sunda, W.G., Huntsman, S.A., 1998. Processes regulating cellular metal accumulation and physiological effects: phytoplankton as model systems. Science of the Total Environment 219, 165-181.

Wang, N., Eckmann, R., 1994. Distribution of perch (Perca fluviatilis L.) during their first year of life in Lake Constance. Hydrobiologia 277, 135-143.

Wang, W.-X., Fisher, N.S., 1997. Modeling the influence of body size on trace element accumulation in mussel Mytilus edulis. Marine Ecology Progress Series $161,103-115$

Wang, W.-X., Rainbow, P.S., 2005. Influence of metal exposure history on trace metal uptake and accumulation by marine invertebrates. Ecotoxicology and Environmental Safety 61, 145-159.

Wang, W.-X., Rainbow, P.S., 2006. Subcellular partitioning and the prediction of cadmium toxicity to aquatic organisms. Environmental Chemistry 3, 395-399.

Wright, D.A., 1995. Trace metal and major ion interactions in aquatic animals. Marine Pollution Bulletin 31, 8-18. 